\title{
Effect of Crude Oil Contaminated Soil on Phaseolus Vulgaris L
}

\author{
Adeyemi O, Adeyemi O
}

\begin{abstract}
Effect of crude oil contaminated soil on physical and biochemical propertiesof beans (Phaseolus vulgaris) was investigated. Thirty polythene pots, each containing $10 \mathrm{~kg}$ of surface soil, were randomly placed on a table in the screenhouse in a factorial combination of five treatment levels $(0.4 \%, 0.3 \%$, $0.2 \%, 0.1 \%$ and $0 \%$ w/w) of crude oil and were designated $P 4$, P3, P2, P1 and P0respectively. Three seeds of beans per pot were planted. Growth parameters (plant height, stem girth, relative water content (RWC), and soluble protein content (SPC)) and antioxidant indices were determined in the beans over a period of nine weeks after planting (WAP). Results showed that growth of beans planted in contaminated soil was significantly lower $(\mathbf{p}<0.05)$ than that of control. Beans planted in the contaminated soil also showed a significant increase $(\mathbf{p}<0.05)$ in superoxide dismutase (SOD), catalase (CAT), peroxidase (POD), ascorbate peroxidase (APX) and glutathione reductase (GR) activities in leaves when compared with control plants. The results suggest that crude oil contaminated soil hindered availability of water, air and nutrients to beans roots, creating a drought condition which could induce oxidative stress in the plant and consequently retarding growth and yield of beans plant.
\end{abstract}

Index Terms - Toxicological, crude oil, Phaseolus vulgaris, soil, biochemical.

\section{INTRODUCTION}

Crude oil is a complex mixture of thousands of hydrocarbons and non-hydrocarbon compounds, including heavy metals. Nigeria is an established crude oil exporting nation producing medium and light crude oil, such as bonny light [1]. Crude oil exportation is the main stay of Nigeria's economy. Crude oil is a colloidal mixture of different hydrocarbons (90\%) and non-hydrocarbon (10\%) components [2]. Various activities in crude oil exploration, exploitation, storage and transportation lead to spillage of oil to the environment [3]. Crude oil causes harmful effects on the environment, where it poses a serious threat to organisms and farmland that are linked in a complex food chain that includes humans [4]. The effects of crude oil on the growth and performance of plants have been reported in many studies [5], [6]. Crude oil in soil makes the soil condition unsatisfactory for plant growth. It can reduce the level of available plant nutrient in contaminated soils and can also raise the levels of certain elements such as iron and zinc

Adeyemi O, Department of Environmental Management and Toxicology, Federal University of Petroleum Resources, Effurun, Delta State, Nigeria

Adeyemi O, Department of Environmental Management and Toxicology, Federal University of Petroleum Resources, Effurun, Delta State, Nigeria to toxic amounts [7]. Water and oil are usually considered to be immiscible. However, crude oil contains a very small soluble portion referred to as the water soluble fraction (WSF). The soluble constituents are dispersed particulate oil, dissolved hydrocarbons and soluble contaminants such as metallic ions. The components of crude oil that go into solution make up the WSF. The lower the molecular weight of the constituent hydrocarbon of crude oil, the higher is its concentration in the water-soluble fraction [8].

Crude oil is the largest and most important source of hydrocarbons [9]. It varies in appearance and composition from one oil kind to another [10]. The varying compositions of one crude oil from the other have diverse effects on different organisms within the same environment [11]. However, crude oil is not found naturally in every part of the world. It is transported from one place to other for refining. A seemingly inescapable consequence of these transport activities is the accidental spill of the oil into both land and water. Crude oil pollution has been reported to have deleterious effects on plant germination and seedling growth [5], [12].

Exposure of plants to crude oil and heavy metal poisoning has been reported to produce reactive oxygen species (ROS) and other free radicals which induce oxidative stress and cause lipid peroxidation [13]. Even at an early stage, it can cause a reduction in cell proliferation and growth. Various researchers have reported activation of lipid peroxidation in plants exposed to different pollutants [14]. Increase in superoxide dismutase (SOD) activity has also been reported in oat, wheat and Arabidopsis thaliana in soils contaminated with various pollutants [15]. Several plant species have also been shown to have elevated peroxidase activities in response to increased pollutant concentrations [16]. Reactive oxygen species is thought to increase cellular damage through the oxidation of several macromolecules such as lipids and proteins [17]. Scanty information is available in literature on the effect of crude oil-impacted soil on Phaseolus vulgaris $L$. (common beans).

The common beans or Phaseolus vulgaris L., is the most important food legume for direct consumption in the world. Among major food crop, it has one of the highest levels of variation in growth habit, seed characteristics (size, shape, colour), maturity, and adaptation. It also has a tremendous variability (> 40,000 varieties). In Africa, beans are grown 
mainly for subsistence, where the Great Lakes region has the highest per capita consumption in the world. Beans are a nearly "perfect" food. Nutritionally rich, they are also a good source of protein, folic acid, dietary fibre and complex carbohydrates. Beans are also one of the best non-meat sources of iron, providing $23-30 \%$ of daily recommended levels [18] from a single serving. Consumption of beans is high mostly because they are a relatively inexpensive food. For the poor of the world, they are a means of keeping malnutrition at bay [19]. Legumes play an important role in the restoration and sustenance of soil fertility through their ability to fix atmospheric nitrogen in partnership with certain bacterial species. Owing to this overriding role of legumes in agriculture, their growth and survival in arable lands become paramount, particularly now that many farm lands are fast losing their agricultural value due to pollution and overuse.

This research work is geared towards outlining the effect of soil contaminated with crude oil (at various levels) on the biochemical properties and growth rate of beans (phaseolus vulgaris). Bioassays such as measurements of seed germination and early seedling growth have been used to monitor treatment effects of oil-contaminated sites [20].

Crude oil and its products are made up of aliphatic, oleic, naphthenic and aromatic hydrocarbons, which change the physical and chemical properties of soil and its structure [21]. These compounds are largely responsible for altered fertility of soil. Affected soils lose their biological activity and many require up to ten years recovering [22]. This has necessitated the current investigation in Nigeria where a lot of pollution of farmlands by crude oil occurs.

\section{MATERIALS AND METHODS}

\section{Reagents}

Reagents and solvents were of analytical grade and are products of British Drug House, Poole, England.

\section{Crude oil}

The crude oil sample was collected from Warri Refinery and Petro-chemical Companies (WRPC) Warri Delta State, Nigeria.

\section{Experimental design and agronomic details}

The experiment was conducted in a screenhouse of the College of Science, Federal University of Petroleum Resources, Effurun, Nigeria. The method described by Adewole and Aboyeji[23] though slightly modified was used. Bulk surface soil samples $(0-15 \mathrm{~cm})$ were collected from an area in the University, air-dried for seven days, sieved using 2 $\mathrm{mm}$ sieve and analysed using standard methods. Thirty polythene pots with drainage holes at the bottom, each containing $10 \mathrm{~kg}$ of surface soil, were randomly placed on a table in the screenhouse in a factorial combination of five treatment levels $(0.4 \%, 0.3 \%, 0.2 \%, 0.1 \%$ and $0 \% \mathrm{w} / \mathrm{w})$ of crude oil and designated S4, S3, S2, S1 and S0 respectively. The soil inside the pots, homogenized by stirring using a glass rod, wetted with distilled water and allowed to equilibrate for two weeks. Two weeks after the application of crude oil, three seeds of beans/guinea corn (obtained from Effurun market, Effurun, Nigeria) per pot were planted. The bean stands were regularly watered throughout the growing stage. The beans/guinea corn plants were thinned to two stands per pot at two weeks after planting (WAP). The thinned stands were retained inside the pots from which they were removed so as to put back into the soil what might have been taken up by the plant within the first two weeks of growth. Fortnightly, growth parameters of maize such as plant height and stem girth were measured till nineWAP when the experiment was terminated.

\section{Relative Water Content (RWC) Determination}

Relative water content (RWC) of leaves was determined at 9 WAP by the standard method [24].

Two leaves from each plant were harvested and weighed to obtain the fresh weight.The leaves were then floated in a closed Petri dish containing distilled water for 4hours.After 4hours, the leaves were dried with filter paper and weighed immediately to obtain the turgid weight. The leaves were then oven dried at $80^{\circ} \mathrm{C}$ for $24 \mathrm{hrs}$, then cooled in a dessicator for 1hour. After cooling, the leaves were weighed and recorded as the dried weight.

The relative water content (RWC) was calculated as; RWC $\%=\frac{\text { (Fresh weight }- \text { dry weight) } \mathrm{X} 100}{\text { (Turgid weight }- \text { dry weight) }}$

\section{Soil analysis}

The $\mathrm{pH}$, temperature, moisture content, soil particle size, phosphorus, potassium, sodium, calcium, and magnesium content of the soils were analyzed using the conventional standard methods by Black, [25] AOAC [26]; APHA/AWWA [27].

\section{Determination of Toxicological Indices}

The protein content in the tissue of experimental plants was determined following the method reported by Gornalet al[28].The malondialdehyde (MDA) concentration in the serum and tissues of rats experimental was determined following the method described by Bird et al.[29]. The Reduced Glutathione (GSH) concentration in the tissues of experimental plants was determined following the method described by Jollowet al,[30]. The Superoxide Dismutase (SOD)activity of the tissues of experimental animals was determined following the method described by Misra and Fridovich[31]. The catalase activity of the tissue homogenate obtained from the experimental plant was determined following the method described by Sinha[32]. The activity of ascorbate peroxidase was assayed by the method of Nakano and Asada [33].Peroxidase activity was determined specifically by the method of Putter, [34]. 


\section{RESULTS}

Figure 1 shows the effect of crude oil-impacted soil on height of beans over a period of nine weeks. The height of plants in the 4 treatment groups (P0.1, P.02, P0.3 and P0.4) progressed positively as the Control. By 7 WAP the height of control emerged significantly higher $(p<0.05)$ than the plant in the treatment groups and the pattern was maintained till the end of the experiment. Among the treatment groups, the height of P0.4 plant was found to be significantly lower $(\mathrm{p}<0.05)$ than any other treatment groups (P0.1, P0.2, and P0.3).

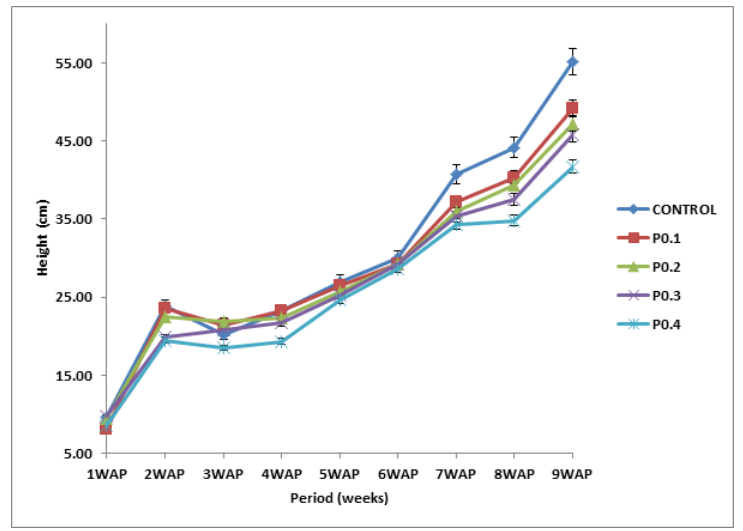

Figure 1: Effect of crude oil-impacted soil on height of beans over a period of nine (9) weeks. Results are means of 5 determinations \pm SEM.

WAP: weeks after planting

Figure 2 shows the effect of crude oil-imparted soil on stem girth of beans over a period of nine (9) weeks. Stem girth of plant in treatment groups (P0.1, P.02, P0.3 and P0.4) were found to be significantly lower $(\mathrm{p}<0.05)$ relative to control from the $3 \mathrm{WAP}$ through to the end of the experiment. No significant difference $(p>0.05)$ was found between the stem girth of plants in groups P0.1 and P0.2. Conversely, stem girth of plants in group $\mathrm{P} 0.3$ was significantly higher than that of P0.4. Worthy of note is the observation at 2WAP when the stem girth of experimental plants decrease significantly $(\mathrm{p}<0.05)$ relative to $1 \mathrm{WAP}$.

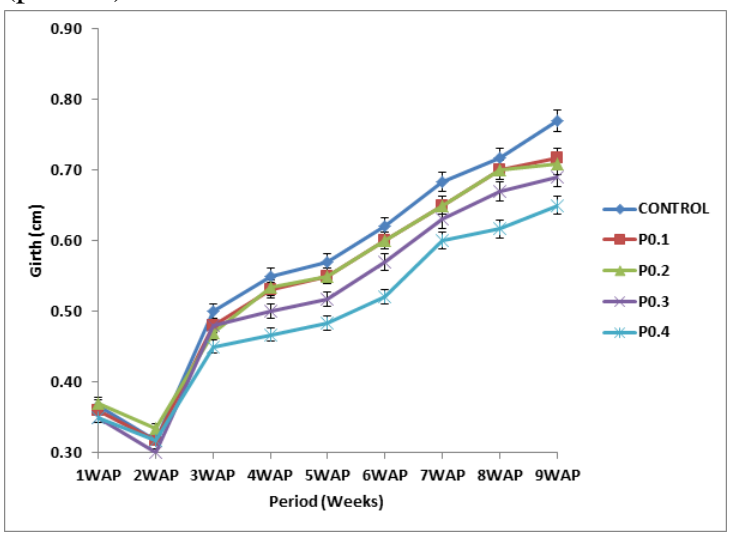

Figure 2: Effect of crude oil-imparted soil on stem girth of beans over a period of nine (9) weeks. Results are means of 5 determinations \pm SEM.

WAP: weeks after planting

The relative water content (RWC) of beans planted in crude oil impacted soil is presented in Figure 3. No significant difference ( $p \geq 0.05$ ) was observed between the RWC of plant in P0.3 and P0.4, RWC decreased significantly $(\mathrm{p}<0.05)$ in plants as the concentration of crude oil increased in the soil. Relative to the control, RWC of plants in the treatment groups was found to be significantly lower $(\mathrm{p}<0.05)$.

Activities of SOD of leaves of beans increased significantly $(\mathrm{p}<0.05)$, relative to the control, as the concentration of crude oil in soil increased (Table 1). Relative to the control, activities of CAT of leaves of beans was found to be significantly higher

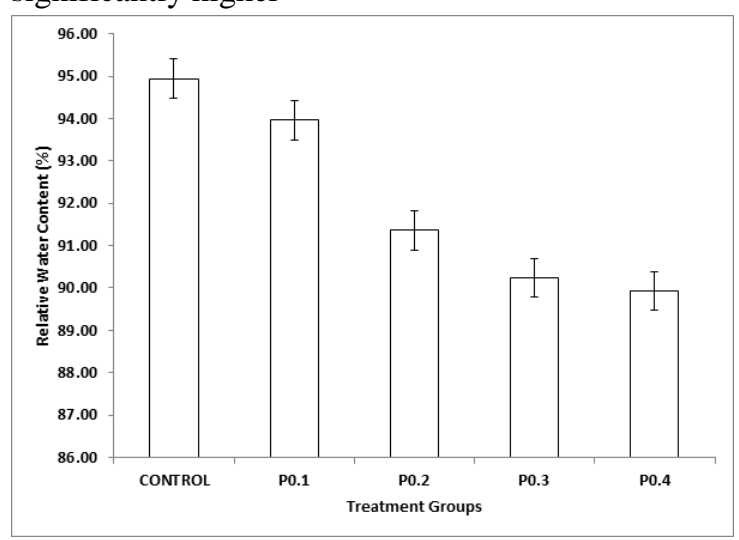

Figure 3: Effect of crude oil-impacted soil on the relative water content (RWC) of planted beans over a period of nine (9) weeks.

$(\mathrm{p}<0.05)$ in other treatment groups except P0.1. Similarly, activities of POD, APX and GR of leaves of plants in the treatment groups were found to be significantly higher $(p<0.05)$ than that of the control. The activity of APX of leaves of plant in P0.4 is about $2 \frac{1}{2}$ folds that of control.

Table 1 Effect of crude oil-imparted soil on activities of superoxide dismutase (SOD), catalase (CAT), peroxidase (POD), ascorbate peroxidase (APX)and glutathione reductase (GR) activities of beans leaves

\begin{tabular}{|c|c|c|c|c|c|}
\hline GROUPS & $\begin{array}{l}\text { SOD (units } \\
\text { mg }^{-1} \text { protein) }\end{array}$ & $\begin{array}{l}\text { CAT ( } \text { Cmol }^{-1} \\
\mathbf{H}_{2} \mathbf{O}_{2} \text { min }^{-1} \\
\text { mg }^{-1} \text { protein) }\end{array}$ & $\begin{array}{l}\text { POD (Units } \\
\text { mg }^{-1} \text { protein) }\end{array}$ & $\begin{array}{l}\text { APX }(\mu \text { mol } \\
\text { ascorbate min }^{-1} \\
\text { mg }^{-1} \text { protein) }\end{array}$ & $\begin{array}{l}\text { GR }\left(\mu \mathrm{mol}^{\mathrm{Gol}}\right. \\
\text { NADPH min } \\
\text { mg }^{-1} \text { protein) }\end{array}$ \\
\hline Control & $23.14 \pm 1.11^{a}$ & $1.13 \pm 0.22^{\mathrm{a}}$ & $7.24 \pm 0.25^{\mathrm{a}}$ & $1.14 \pm 0.01^{a}$ & $10.07 \pm 0.19^{\mathrm{a}}$ \\
\hline P0.1 & $25.22 \pm 0.98^{\mathrm{b}}$ & $1.56 \pm 0.25^{\mathrm{ab}}$ & $8.14 \pm 0.28^{b}$ & $1.35 \pm 0.02^{b}$ & $11.25 \pm 0.18^{\mathrm{b}}$ \\
\hline P0.2 & $29.37 \pm 1.01^{c}$ & $1.82 \pm 0.17^{\mathrm{bc}}$ & $8.57 \pm 0.32^{\mathrm{b}}$ & $1.98 \pm 0.01^{\mathrm{c}}$ & $12.02 \pm 0.20^{c}$ \\
\hline P0.3 & $42.18 \pm 2.34^{\mathrm{d}}$ & $2.17 \pm 0.26^{\mathrm{c}}$ & $9.54 \pm 0.23^{\mathrm{c}}$ & $2.22 \pm 0.01^{d}$ & $12.45 \pm 0.15^{\mathrm{c}}$ \\
\hline P0.4 & $55.27 \pm 2.87^{\mathrm{e}}$ & $2.82 \pm 0.29^{\mathrm{d}}$ & $11.02 \pm 0.41^{\mathrm{d}}$ & $2.78 \pm 0.03^{\mathrm{c}}$ & $13.19 \pm 0.21^{\mathrm{d}}$ \\
\hline
\end{tabular}

Values are means \pm SEM of six determinations.

${ }^{a, b, c}$ Column values with different superscripts are significantly different $(\mathbf{p}<\mathbf{0 . 0 5})$.

Table 2 presents activities of selected enzymes of stem of beans plant in crude oil impacted soil. Generally, activities of enzymes of stem of plant in the treatment groups increased significantly $(p<0.05)$ relative to the control. However, except the activities of CAT and APX of stem of P0.1 activities of other enzymes are not significantly different ( $>0.05)$ from the control. 
Table 2 : Effect of crude oil-imparted soil on activities of superoxide dismutase (SOD), catalase (CAT), peroxidase (POD), ascorbate peroxidase (APX)and glutathione reductase (GR) activities of beans stems

\begin{tabular}{|c|c|c|c|c|c|}
\hline GROUPS & $\begin{array}{l}\text { SOD (units } \\
\text { mg }^{-1} \text { protein) }\end{array}$ & $\begin{array}{l}\text { CAT ( } \mu \text { mol }^{-1} \\
\mathbf{H}_{2} \mathbf{O}_{2} \text { min }^{-1} \\
\text { mg }^{-1} \text { protein) }\end{array}$ & $\begin{array}{l}\text { POD (Units } \\
\text { mg }^{-1} \text { protein) }\end{array}$ & $\begin{array}{l}\text { APX ( } \mu \text { mol } \\
\text { ascorbate min }^{-1} \\
\text { mg }^{-1} \text { protein) }\end{array}$ & $\begin{array}{l}\text { GR }\left(\mu \quad \text { mol }^{-1}\right. \\
\text { NADPH min } \\
\text { m }^{-1} \text { protein }\end{array}$ \\
\hline Control & $12.01 \pm 1.22^{\mathrm{a}}$ & $0.75 \pm 0.04^{a}$ & $4.21 \pm 0.72^{2}$ & $0.68 \pm 0.01^{a}$ & $5.15 \pm 1.32^{a}$ \\
\hline P0.1 & $14.32 \pm 0.78^{\text {ab }}$ & $1.09 \pm 0.11^{\mathrm{b}}$ & $5.86 \pm 0.88^{\mathrm{a}}$ & $0.95 \pm 0.01^{\mathrm{b}}$ & $6.92 \pm 0.99^{\mathrm{a}}$ \\
\hline P0.2 & $15.19 \pm 1.19^{\mathrm{b}}$ & $1.56 \pm 0.08^{\mathrm{c}}$ & $6.32 \pm 0.84^{\mathrm{b}}$ & $1.22 \pm 0.03^{\mathrm{c}}$ & $9.81 \pm 1.13^{\mathrm{b}}$ \\
\hline P0.3 & $18.85 \pm 1.32^{c}$ & $2.58 \pm 0.09^{\mathrm{d}}$ & $9.05 \pm 0.76^{\mathrm{c}}$ & $1.78 \pm 0.05^{\mathrm{d}}$ & $11.73 \pm 1.10^{\mathrm{bc}}$ \\
\hline P0.4 & $20.17 \pm 1.10^{c}$ & $3.35 \pm 0.14^{e}$ & $10.45 \pm 0.95^{\mathrm{c}}$ & $2.45 \pm 0.06^{\mathrm{e}}$ & $12.56 \pm 1.05^{\mathrm{c}}$ \\
\hline
\end{tabular}

Values are means \pm SEM of six determinations.

a,b,c Column values with different superscripts are significantly different $(\mathbf{p}<0.05)$.

The concentrations of SPC and MDA of leaves of beans planted in crude oil impacted soil are presented in Table 3. The SPC of leaves of plant in treatment groups was found to be significantly lower $(\mathrm{p}<0.05)$ relative to the control while the MDA concentration was significantly higher $(\mathrm{p}<0.05)$ relative to the control. SPC of leaves of plant in $\mathrm{P} 0.2, \mathrm{P} 0.3$ and P0.4 were found not to be significantly different $(\mathrm{p}<0.05)$ while the MDA of leaves of P0.3 and P0.4 were found to be significantly higher than plant in P0.2.

Table 3: Effect of crude oil-impacted soil on soluble protein content (SPC) and malondialdehyde (MDA) of beans leaves

\begin{tabular}{lll}
\hline GROUPS & SPC $\left(\mathrm{mg} \mathrm{g}^{-1} \mathrm{FW}\right)$ & MDA $\left(\mu \mathrm{mol} \mathrm{g}^{-1} \mathrm{FW}\right)$ \\
\hline Control & $5.56 \pm 0.84^{\mathrm{a}}$ & $1.46 \pm 0.03^{\mathrm{a}}$ \\
P0.1 & $5.12 \pm 0.57^{\mathrm{hb}}$ & $1.72 \pm 0.05^{\mathrm{b}}$ \\
P0.2 & $4.96 \pm 0.51^{\mathrm{be}}$ & $2.03 \pm 0.05^{\mathrm{c}}$ \\
P0.3 & $4.43 \pm 0.39^{\mathrm{c}}$ & $2.17 \pm 0.07^{\mathrm{d}}$ \\
P0.4 & $4.04 \pm 0.38^{\mathrm{c}}$ & $2.24 \pm 0.03^{\mathrm{d}}$ \\
\hline
\end{tabular}

Values are means \pm SEM of six determinations.

${ }^{a, b, c}$ Column values with different superscripts are significantly different $(\mathbf{p}<0.05)$.

Table 4 presents the effect of crude oil-impacted soil on the concentrations of SPC and MDA of stems of beans. The SPC of beans planted in crude oil-impacted soil was significantly lower $(p<0.05)$ than that of control while the MDA of stem of beans planted in crude oil-impacted soil was significantly higher than that of control $(\mathrm{p}<0.05)$. The SPC of beans in P0.4 was about $1 / 2$ that of

Table 4: Effect of crude oil-impacted soil on soluble protein content (SPC) and malondialdehyde (MDA) of beans stems

\begin{tabular}{lll}
\hline GROUPS & SPC $\left(\mathbf{m g ~ g}^{-1} \mathbf{F W}\right)$ & MDA $\left(\mu \mathrm{mol} \mathrm{g}^{-1} \mathbf{F W}\right)$ \\
\hline Control & $1.11 \pm 0.04^{\mathrm{a}}$ & $1.46 \pm 0.03^{\mathrm{a}}$ \\
P0.1 & $0.92 \pm 0.02^{\mathrm{b}}$ & $1.72 \pm 0.05^{\mathrm{b}}$ \\
P0.2 & $0.84 \pm 0.00^{\mathrm{b}}$ & $2.03 \pm 0.05^{\mathrm{c}}$ \\
P0.3 & $0.76 \pm 0.02^{\mathrm{d}}$ & $2.17 \pm 0.07^{\mathrm{d}}$ \\
P0.4 & $0.64 \pm 0.01^{\mathrm{d}}$ & $2.24 \pm 0.03^{\mathrm{d}}$ \\
\hline
\end{tabular}

Values are means \pm SEM of six determinations.

${ }^{a, b, c}$ Column values with different superscripts are significantly different $(\mathbf{p}<0.05)$.

control while the MDA of stem of beans in P0.4 was about two folds that of control.

\section{DISCUSSION AND CONCLUSION}

\section{Discussion}

Crude oil is a complex mixture of thousands of hydrocarbons and non hydrocarbon compounds, including heavy metals. Although the toxicity of each individual component is known, the toxicity of complex mixtures such as crude oils and refined products is extremely difficult to assess, because researchers know little about the additive, synergistic, or antagonistic effects of the various mixtures. In addition, the chemical composition of each crude oil and petroleum product varies significantly, and can have diverse effects on different organisms within the sameecosystem. These differences in toxic effects are due to qualitative compositional differences in the various products, as well as concentration differences of the chemical constituents Bioassays such as measurements of seed germination and early seedling growth have been used to monitor treatment effects and restoration of oil-contaminated sites. The present study investigated the effect of crude oil-impacted soil on beans over a period of nine weeks.

Plants, in general, absorb minerals and water from the soil and respond with growth which is observable by the number of leaves, height, stem girth etc. The observed reduction in the height of beans planted in crude oil-impacted soil (Figure 1) was found to depend on the concentration of the crude oil. This observation suggests that the crude oil hinders and /or reduces water and nutrient available to beans from the soil. Similarly, the stem girth of beans planted in crude oil-impacted soil (Figure 2) was significantly reduced relative to the control suggesting stunted growth. Okon and Udofot[35] reported that Soil nutrients are less mobile in contaminated soils and will adversely alter the growth pattern of plants.

RWC is the appropriate measure of plant water status in terms of the physiological consequence of cellular water deficit, while water potential is an estimate of plant water status and it is useful in dealing with water transport in the soil-plant-atmosphere continuum [36]. In this study, we found that crude oil-impacted soil decreased the RWC at growth stages, especially under high concentration (Figure 3 ). This condition portends stress to the plant and lends credence to the reason adduced to the reduced plant height and stem girth of beans planted in crude oil-impacted soil.

Plant stress invariably leads to oxidative stress in the plant cell due to the higher leakage of electrons towards $\mathrm{O}_{2}$ during photosynthetic and respiratory processes leading to enhancement in reactive oxygen species (ROS) generation [37]. The ROS such as $\mathrm{O}_{2}^{-}, \mathrm{H}_{2} \mathrm{O}_{2}$ and $\mathrm{OH}$ radicals have potential to interact with many cellular components, causing significant damage to membrane and other cellular structures, and consequently growth inhibition [37]. Some of the ROS are highly toxic and must be detoxified by cellular responses if the plant survives and grows. The ROS scavenging depends on the detoxification mechanism, which may occur as a result 
of sequential and simultaneous action of a number of antioxidant enzymes, including superoxide dismutase (SOD), catalase (CAT), peroxidase (POD), ascorbate peroxidase (APX) and glutathione reductase (GR).

The present study revealed significant increase in the activities of antioxidant enzymes of both leaves and stems of beans planted in contaminated soil relative to the control (Tables 1 and 2). Again, as observed in Tables 3 and 4 the concentration of MDA in both leaves and stems in beans planted in crude oil-impacted was significantly higher relative to the control. It therefore implies that, the beans plant is subjected to oxidative stress thereby reducing the nutrient and water uptake capability and ultimately hindering plant growth. The underlying mechanism of our submission is unclear however, low water, the major nutrient transport vehicle; uptake predisposes the plant to concentrate metabolites.

\section{Conclusion}

In conclusion, experimental evidence from this study suggests phytophysiological dysfunction in beans planted in crude oil-impacted soil. This underscores the need for careful transportation of crude oil to avoid accidental spills and quick response to curtail such spills. This also sounds a serious warning to crude oil vandals to desist from such as because crude oil impacted soil may reduce agricultural produce which will in turn lead to shortage of food and reduced national income.

Studies are underway to determine theeffect of crude oil impacted soil on non enzymic antioxidants, nutrients and cytotoxicologyof beans. These ongoing studies will enhance our understanding of the impact and enable an all-encompassing remediation strategy when accidental oil spills occur on farmland.

\section{REFERENCES}

[1]. Amund, O.O., Akangou, T.S. 1993. Microbial degradation of four Nigerian crude oils in an estuarine microcosm. LettApplMicrobiol. 16, 118-121

[2]. Cadwellaer, S. 1993. Encyclopaedia of Environmental Science and Engineering. 4th ed.

[3]. Agbogidi, O.M., Ernotor, P.G., Akparobi, S.O. 2007. Effects of crude oil levels on the growth of maize (Zea mays L.) Am J Food Tech. 2, 529-535.

[4]. Lundstedt, .S. 2003. Analysis of PAHs and their transformation products in contaminated soil and remedial processes. Solfjodern Offset AB, Umea, Sweden, pp. 55

[5]. Adeyemi, O., Adeyemi, O., Osubor C.C. 2016. The Effects of Crude Oil Impacted Soil on the Biochemical Properties of Guinea Corn. NISEB Journal16 (3), 85-92.

[6]. Njoku, K.L., Akinola, M.O., Oboh, B.O. 2008. Growth and performance of Glycine max L. (Merrill) grown in crude oil contaminated soil augmented with cow dung. Nature and Science. 6,48-56

[7]. Udo, E.J., Fayemi, A.A. 1975. The effect of oil pollution of soil on germination, growth and nutrient uptake of corn. J Environ Qual. 4, 537-540

[8]. Edema, N. 2012. Effects of Crude Oil Contaminated Water on the Environment. In: Crude Oil Emulsions- Composition Stability and Characterization. [Manar El-Sayed Abdul-Raouf (Ed.)]. InTech. 9, 170-180

[9]. Hunt, J.M. 1996. Petroleum Geochemistry and Geology; 2nd Edition.

[10]. Craig, C.F. 2003. Occupational safety and health administration. Washington D.C. 20210.
[11]. Overton, E.B., Sharp, W.D., Roberts, P. 1994. Toxicity of petroleum. In Basic Environ. Toxicol. CRC Press: Boca Raton, FL. Pp. 133-156.

[12]. Kyung-Hwa, B., Hee-Sik, K., Hee-Mock, O., Byung-Dae, Y., Jaisoo, K., In- Sook, L. 2004. Effect of crude oil, oil components, and bioremediation on plant growth, J. Environ.Sci. health. 39 (9), 2465-2472.

[13]. Blokhina, O.B., Fagerstedt, K.V., Chirkova, T.V. 1999. Relationship between lipid peroxidation and anoxia tolerance in a range of species during post-anoxic re-aeration. Physiol Plant. 105(4), 626-632.

[14]. Chirkova, T.V., Novitskaya, L.O., Blokhina, O.B. 1998. Lipid peroxidation and antioxidant systems under anoxia in plants differing in their tolerance to oxygen deficiency. Russian J. Plant Physiol45, $55-62$.

[15]. Alscher, R.G., Erturk, N., Heath, L.S. 2002. Role of superoxide dismutases (SODs) in controlling oxidative stress in plants. J. Exp. Bot.53,1331-1341.

[16]. Jouili, H., Ezzedine, E.F. 2003. Changes in antioxidant and lignifying enzyme activities in sunflower roots (Helianthus annuusL.) stressed with copper excess. C. R. Biol. 326, 639-644.

[17]. Ortega-Villasante, C., Rellán-Álvarez, R., del Campo, F.F., Carpena-Ruiz, R.O., Hernández, L.E. 2005. Cellular damage induced by cadmium and mercury in Medicago sativa. J Expt Bot.56, 2239-2251.

[18]. Pachico, D. 1993. The demand for bean technology. Trends In CIAT commodities 1993. Working document No. 128. Pp. 60-74. Henry, G.,ed. Centro Internacional de Agricultura Tropical (CIAT), Calt, Colombia.

[19]. WHO. 1992. The Global Climate System. Climate System Monitoring Dec 1988- May 1991. Pp. 73-74. WHO World Climate Data Monitoring Programme, United Nations Environment Programme (UNEP), Nairobi, Kenya.

[20]. Sverdrup, L.E., Krogh, P.H., Nielsen, T., Kjær, C., Stenersen, J. 2003. Toxicity of eight polycyclic aromatic compounds to red clover (Trifolium pretense), ryegrass (Loliumperenne), and mustard (Sinapsisalba). Chemosphere. 53, 993-1003.

[21]. Chi, Y.F., Krishnamurthy, M. 1995. Enzymes for enhancing bioremediation of petroleum contaminated soils: A brief review. Air Waste Manage. Assoc. 45, 453-460.

[22]. Wyszkowska, J. Kucharski, J., Jastrzebska, E., Illasko, A. 2001. The biological properties of the soil as influenced by chromium contamination. Polish J. Environ. Stud. 10, 37-42.

[23]. Adewole, M.B., Aboyeji A.O. 2013. Yield and quality of maize from spent engine oil contaminated soils amended with compost under screenhouse conditions. J Agrobiol30, 9-19.

[24]. Schonfeld, M.A., Johnson, R.C., Carver, B.F., Mornhinweg, D.W. 1988. Water relations in winter wheat as drought resistance indicator. Crop Sci28, 526-531).

[25]. Black, C.A. 1982. Methods of soil analysis. AmerSocAgron Madison Wisconsin. Agronomy Part 2 No: 9.

[26]. AOAC. 1996. Official Methods of Analysis. Association of Official Analytical Chemists. Washington DC P14.

[27]. APHA/AWWA. 1985. Standard methods for the examination of water and waste water quality. J Environ Toxicol Water qual11, 72-82.

[28]. Gornal, A.G., Bardawill, J.C., David, M.M. 1949. Determination of serum proteins by means of biuret reaction J. Biol. Chem. 177, 751-760

[29]. Bird, R.P., Drapper, H.H., Valli, V.E. 1982. Toxicological evaluation of Malondialdehyde: a 12-month study of mice. J. Toxicol. Environ. Health10, 897-905.

[30]. Jollow, D.J., Mitchell, J.R., Gillette, J.R. 1974. Bromobenzene induced liver necrosis: Protective role of glutathione and evidence for 3,4-Bromobenzene oxide as the hepatotoxic metabolite. Pharmacol. 11, 151-169.

[31]. Misra, H.P., Fridovich, I. 1972. The role of superoxide anion in the antioxidation of epinephrine and a simple assay of superoxide dismutase. J. Biol. Chem. 2417-3170

[32]. Sinha, K.A. 1971. Colorimetric assay of catalase. Anal. Biochem. 47, 389-394.

[33]. Chin-A-Woeng, T.E.C., Bloemberg, G.V., Van der Bij, A.J., Van der Drift, K.M., Schripsema, J., Kroon, B., Scheffer, R.J., Thomas, J.E., Luternberg, B.J. 1998. Biocontrol by Phenazine-I-carbonxamide producing Pseudomonas ChlororaphisPCL 1391 of tomato rot caused by Fusariumoxysporum F. Sp. Radicis-lycopercisi. Mol. Plant Microbe Interact. 11, 1069-1077.

[34]. Okon, I.E., Udofot, E.E. 2012. Response of Telfairiaoccidentalis (Hook) to arbuscularmycorrhizal fungi and Gliricidiasepium leaves manure in spent engine oil contaminated soil. World J AgricSci8, 20-25.

[35]. Islam, M.R., Xue, X., Mao, S., Ren, C., Eneji, A.E. 2011a. Effects of water-saving superabsorbent polymer on antioxidant enzyme 
activities and lipid peroxidation in oat (AvenasativaL) under drought stress. J Sci Food Agric91, 680-686.

[36]. Islam, M.R., Hu, Y., Mao, S., Jia, P., Eneji, A.E. 2011b. Effects of water-saving superabsorbent polymer on antioxidant enzyme activities and lipid peroxidation in corn (ZeamaysL.) under drought stress. J Sci Food Agric91, 813-819.

[37]. Adeyemi, O. 2014. The Effect of Palm Kernel Oil (PKO) Biodiesel-Contaminated Soil on Morphological and Biochemical Properties of Zeamays. J Plant BiochemPhysiol138 (2): 1-6. 